$\xi=-1$

\title{
Designing New Financial Instruments to Work in the Asian Markets
}

\author{
Peter Viktorovich Akinin, Valentina Petrovna Akinina, Inna Olegovna Alimova, Yuliya Olegovna Boldareva, Na- \\ talya Valeryevna Viderker
}

North-Caucasus Federal University, Russia, Stavropol, 355009, Pushkina St., 1

\begin{abstract}
This article is the methodology for analyzing the design of new financial instruments associated with the ongoing revolutionary changes in the financial system, the development of financial engineering, which led to the spread of new products that had become available to a wide range of consumers.

Let us select the following tasks:

- to determine the objective need to study the main characteristics of new modified innovative financial products (structured);

- to justify the need to create a completely new financial product determined by the dominant group of goods [typical of the financial markets of the Far East], taking into account their specificity and the change of orientation towards the Asian markets, by the increasing activity in the Eastern vector and by the ability to trade in the national currency;

- to propose and test the methodology for creating a structured financial instrument that meets modern geopolitical challenges, with the inclusion of the price calculated on the basis of the consensus forecast.
\end{abstract}

Keywords: consensus forecast, design, Urals oil, structured financial instrument, commodity exchanges, oil price

\section{Introduction}

A distinctive feature of the development of the modern economy has become the increased role of the stock market, which has acquired a truly global importance in the structure of financial markets. This is due to its ability to attract significant cash flows (for investment, economic modernization, stimulation of production growth, etc.). At the same time, world securities markets, as longterm experience shows, can act as sources of major financial shocks, economic risks and social instability.

One of the modern development trends of innovations in the financial sector [in the stock market] is engineering.

The notion of financial engineering is inherent in financial innovations, which can be defined as the process of creating and popularizing new financial instruments, as well as new financial technologies, institutions and markets [1].

Financial engineering uses tools and knowledge in the field of informatics, statistics, economics and applied mathematics to solve current financial issues, as well as to create and offer new innovative financial products - structured products and instruments [2].

Due to the changing geopolitical situation, the Russian authorities and business pay priority attention to the intensification of economic activity in Siberia and the Far East, international relations with China, India, Japan, South Korea and other Eastern countries. This line of development of the domestic economy received the definition of the Eastern vector.

In turn, the Eastern vector of integration involves the interaction of national systems with the capacity for self-regulation and development based on the alignment of interests of the economy, finance and politics among states. The vector will be directed towards further mutual cooperation taking into account the interests of the countries participating in integration [3].

The presented article offers the methodology for creating such instruments to work in the South-Asian markets.

\section{Methods}

The methods of system and regression analysis, logical modeling, consensus forecast, simulation (time series), and economicmathematical modeling have been used as the research tools.

\section{Results}

The most important results of scientific knowledge increment are as follows:

based on the analysis of monthly reports on the oil market published by EIA (US Energy Information Agency), IEA (International Energy Agency) and OPEC, the Fed's decisions on the key rate, a polynomial model of pricing factors in the stock market has been developed, which allows predicting the price fluctuation limits of the proposed futures contracts;

the method of forecasting fluctuations in prices for the proposed structured product (futures) based on the consensus forecast of price formation in commodity markets has been proposed and tested, which allows determining the changes in oil exchange quotations with the greatest accuracy.

\section{Discussion}

The ongoing revolutionary changes in the economic system, the development of financial engineering, which led to the spread of 
new products that had become available to a wide range of consumers, determine an objective need to study the main characteristics of these new modified innovative products. At the same time, there is a surge of interest in structured financial products both on the part of investors and issuers [4].

The complexity of structured financial products is emphasized in Roberto Knop's monograph [5] devoted to this problem, which provides the following definition:

"A structured financial product is a financial instrument, the profitability of which depends on other, simpler instruments included in its composition. Typically, a structured product consists of credit, its various manifestations, and one or more derivative instruments" [4].

The definition previously considered should be supplemented with the publications of S. Ross who understood "the development of new financial instruments and methods using the existing ones in order to search for financial risk management technology in the fixed-term stock market through hedging operations". He refers to them forward, futures and option contracts, which became also widespread in the Russian securities market [6]. In other words, as Ya.M. Mirkin has emphasized, "the design of securities" takes place.

This definition reveals the following features of structured products:

1. First of all, a structured product is a financial product.
2. Non-standard characteristics of structured products are the basis for achieving specific needs of end users.

3. According to the traditional approach, which is the reference in this work, structured products are complex, composite products that can be presented in the form of an investment basket consisting of simpler components.

4. A structured product is the result of an analysis of the needs of a product user and the design based on that analysis.

One of the features of structured products is the ability to create an almost unlimited number of new innovative modified products as a result of arbitrary design from a limited set of traditional instruments [7].

The basis of structured financial products is hybrid financial instruments.

The design of a structured product will be understood as the process of designing its internal structure by "bundling" various financial instruments, highlighting the basic parameters of the product, their analysis and evaluation in order to create a product that best meets the interests of customers who have their own vision of the market [8]. It should be noted that the process of designing does not include such issues as legal product design, its advertising and marketing, search for potential customers/contractors, their consulting and conclusion of contracts.

The essence of designing a structured product is schematically as follows (Fig.1):

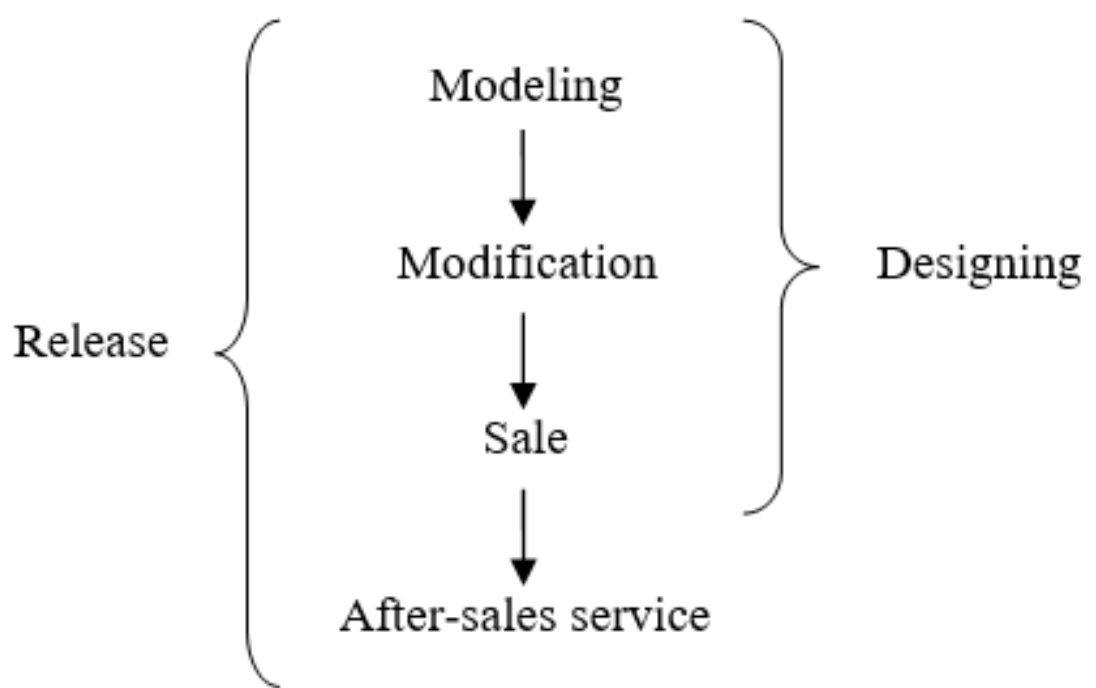

Fig.1: The technology of designing a structured product (authors' development).

The general plan for designing structured products can be conditionally divided into the following stages [9]:

$\checkmark \quad$ Analysis of potential customers' preferences [From the customer's point of view, the parameters of interest of a structured product are]:

- the degree of protection of invested funds (risk management); has a flow forecast; the base pool of assets for which the investor

- the degree of volatility of assets;

- $\quad$ product lifetime; the ability to receive interim payments during the product lifetime, or a preknown fixed payment - a coupon.

Since it is impossible to create template parameters and characteristics for structured products, customers need to conduct a fundamental analysis of the current market situation in order to form their own points of view and their own visions of the market. As a result of this process, preferences are formed, as well as the feasibility of designing a new product.

$\checkmark \quad$ Modeling [includes]:

Traditional financial instruments or their combinations are selected (Fig.2): 
Traditional financial instruments or their combinations are selected
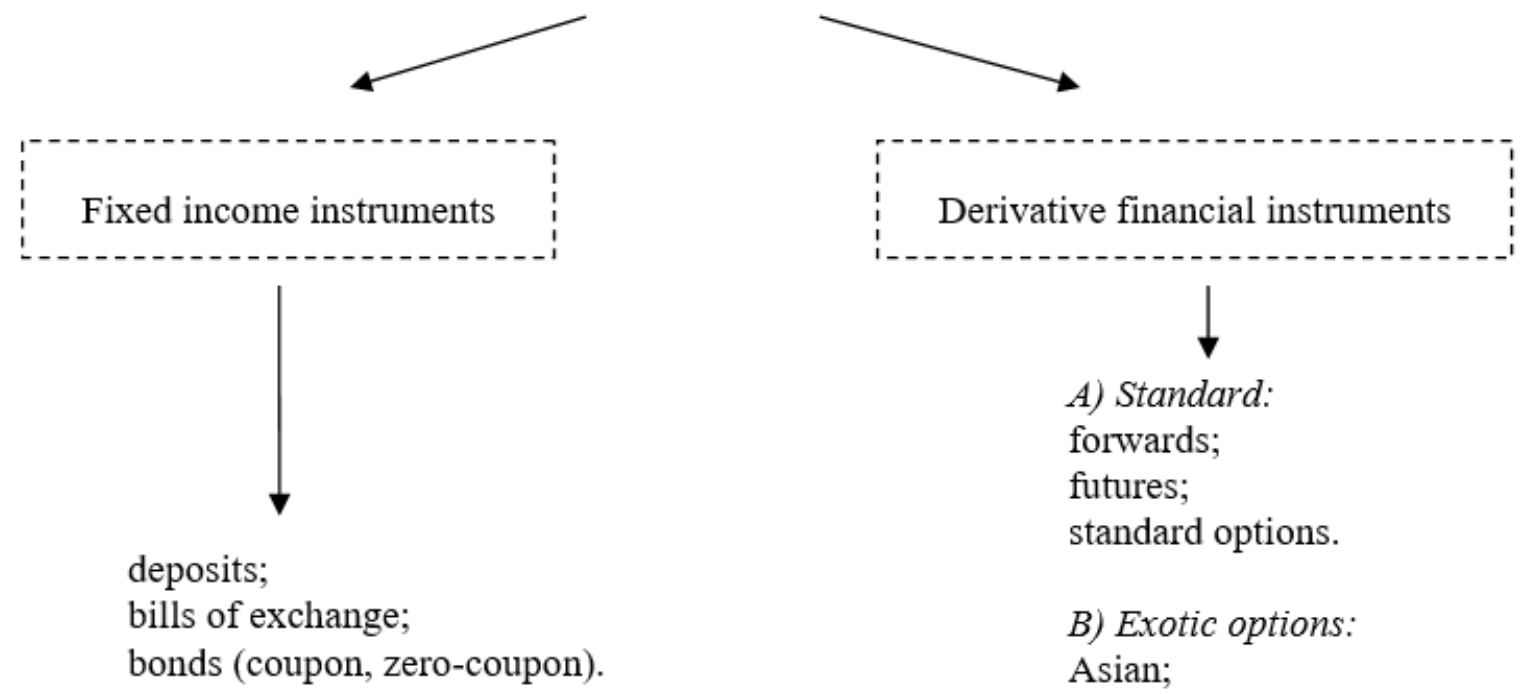

A) Standard:

forwards;

futures;

standard options.

deposits;

bonds (coupon, zero-coupon).

B) Exotic options:

Asian;

barrier;

binary, etc.

Fig.2:. Traditional financial instruments (authors' development).

Fixed income instruments involve the division of the customer's funds into two parts. The first part is responsible for the return of invested capital; in other words, these are financial instruments, the flow of income for which is known in advance. The second part is profitable. Customers choose themselves the risk-free share or the level of capital protection on the basis of their visions of the market.

A structured product is the result of an analysis of the needs of a product user and the design based on that analysis.

The bias towards structured financial products was made from the position that the situation in the Russian stock market began to change radically. The need to create a completely new financial product is determined by the dominant group of products [financial markets of the Far East] taking into account their specificity and the change of focus to the Asian markets, increased activity in the Eastern vector and the ability to trade in the national currency. In the effort to create something new, we start from the favorable experience of the Saint Petersburg Exchange, which in 2016 launched its own futures contract for Urals oil in rubles to refuse the calculation of oil prices in dollars. And since our research touches upon the Eastern vector, we will try to offer the Asian markets a financial instrument in the form of the futures contract for Urals oil, the price of which we will try to create by consensus forecast. The essence of this method was described earlier.

To carry out the calculation part of our research, we have considered several forecasts of the average price of Brent oil for the period from 2000 to 2016 inclusive.

At the moment, the cost of Brent adjusted for inflation is about $13 \%$ below the level of 2000 . This price level is due to oversupply in the world oil market, a high level of oil reserves in the US and political instability in several commodity regions [10].

We have identified macroeconomic indicators that affect price fluctuations in global markets.

Key indicators:

Monthly reports on the oil market published by EIA, IEA and OPEC (usually from the 10th to the 20th of each month - revision of demand/supply forecasts; the Fed's decisions on the key rate;

publication of data on GDP and oil imports in China; publication of financial results of US oil companies; decisions of OPEC meetings.

The US EIA expects the reduction in oil production, which began in May 2015, to continue in 2017 and amount to about 700 thousand barrels/day for a current year.

IEA also predicts a significant decline in production - about 540 thousand barrels/day. Withdrawal from the market of 540-700 thousand barrels/day of oil in 2016 made room for additional oil supplies from Iran and helped to restore the balance of the market. Meanwhile, OPEC expected a more moderate reduction in oil production in the US in 2016 - about 140 thousand barrels/day. According to cartel forecasts, production of tight oil in the US will decrease by 170 thousand barrels/day in 2017 compared to an increase of 440 thousand barrels/day in 2016.

Regarding consumption, low oil prices in 2016-2017 are expected to stimulate additional demand for oil, especially from the countries of Asia and China.

In early 2016, China's financial markets remained under pressure amid concern about the worsening of the country's economic performance, which negatively affected oil quotations. However, the fundamental factors of oil demand in China remain strong. In 2016, oil imports to China increased by 27 million tons compared to 2015 and an increase of 26 million tons in 2015 compared to 2014 [11]

Considering the commercial orientation of commodity exchanges, we have calculated prognostic estimates of the level of Urals oil prices in US dollars.

A combination of two methods was used to obtain prognostic estimates: regression analysis, which made it possible to estimate the dynamics of Urals oil prices and simulation as a parallel method to improve forecasting accuracy.

Based on the results of the consensus forecast, charts of the dynamics of price changes from 2008 to the present have been constructed (Fig.3). The forecast horizon is 3 years, with a reporting period of 10 years. Initial data for plotting the forecast chart: 


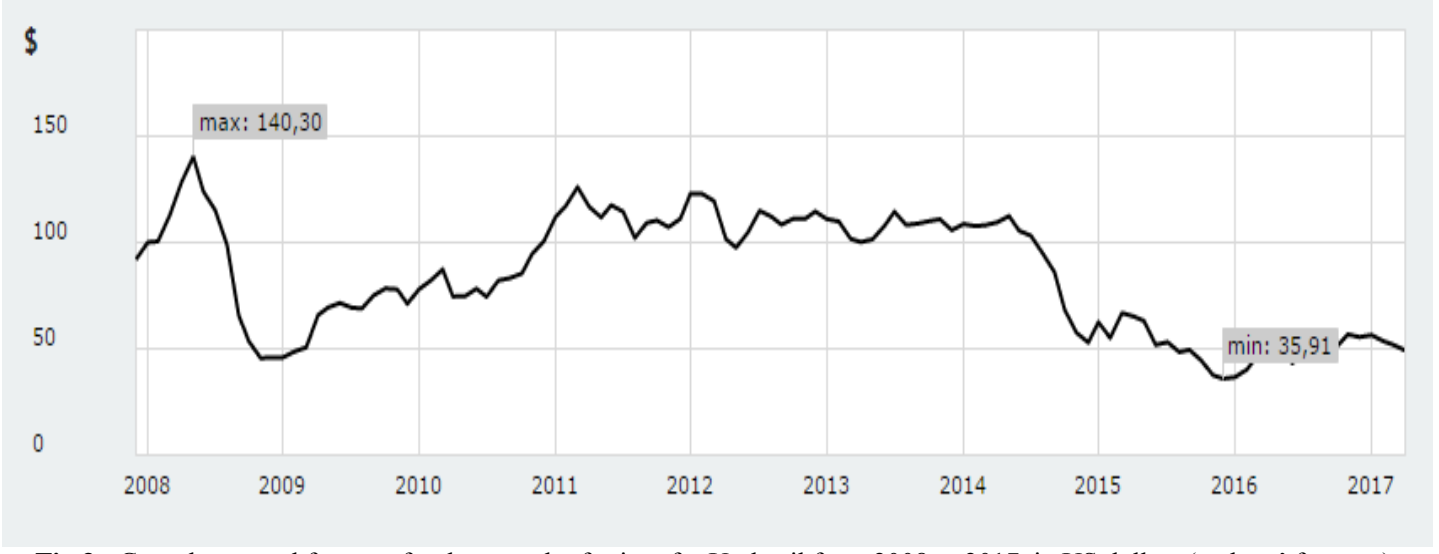

Fig.3:. Growth rate and forecast for the growth of prices for Urals oil from 2008 to 2017, in US dollars (authors' forecast).

Analyzing the dynamics of the projected growth in oil prices, its parabolic form should be noted. Thus, the forecast model is represented by a regression of the form:

$B=a_{0}+a_{1} x+a_{2} x^{2}$, where

$a_{0}$ is the mean value at the beginning of events;

$a_{1}$ is the growth factor;

$a_{2}$ is the growth rate.

The calculation of the model parameters has been determined using the instrumental apparatus of Microsoft Excel, in which regression (1) took the form of a polynomial of the second degree:
$B=4.863 x^{2}+4.5121 x-22.267$

The determinacy coefficient is $R^{2}=0.9862$. The coefficient $R^{2}$ tends to 1 , that is, there is an almost complete correlation with the model, the differences between the actual and estimated values are small [12].

The proposed forecast tool allows accurately determining the fluctuations in oil prices in the short term (day - three days, the forecast accuracy is $85 \%$, Fig.4).

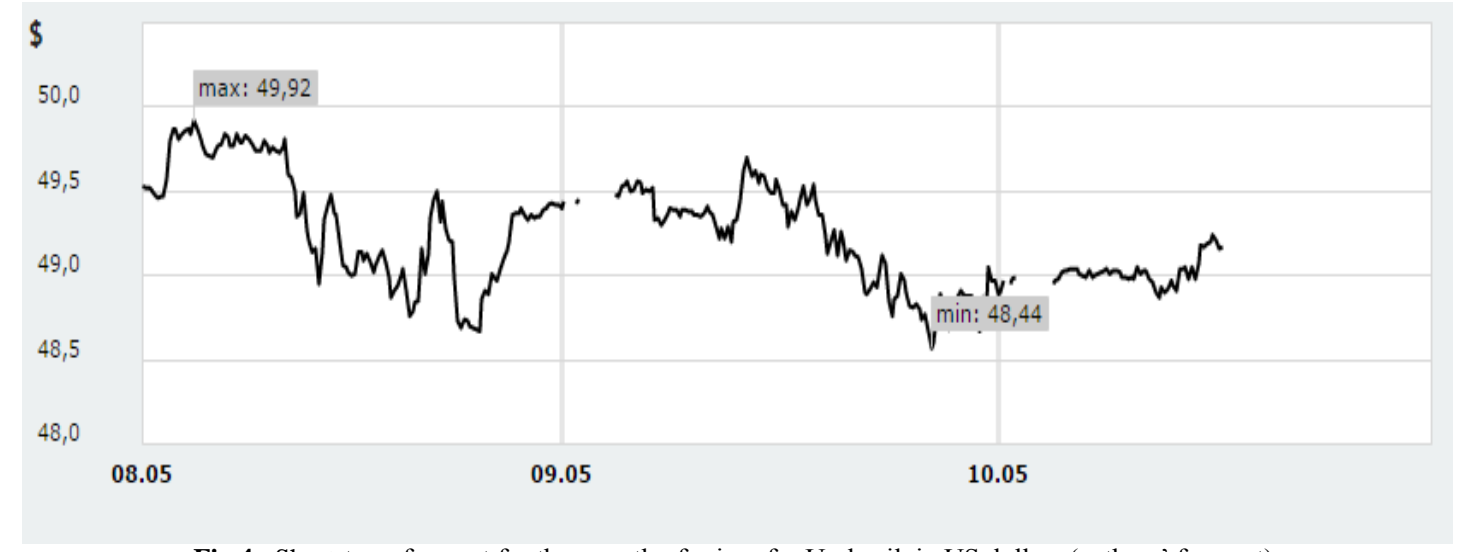

Fig.4:. Short-term forecast for the growth of prices for Urals oil, in US dollars (authors' forecast).

and the long-term -5 years (the forecast accuracy is $79 \%$ ). The strength and accuracy of the forecast in the medium term (from 1 month to 1 year) is $49 \%$ (Fig.5).

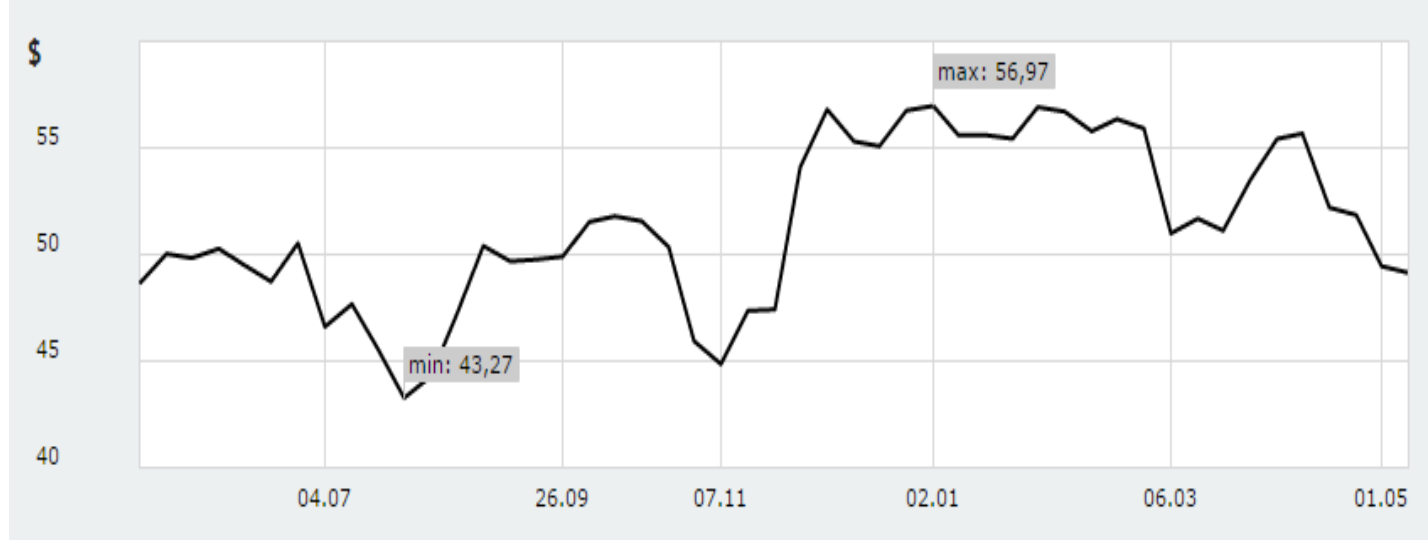

Fig.5:. Medium-term forecast for the growth of prices for Urals oil (12 months), in US dollars (authors' forecast). 
The processes taking place in the world markets significantly affect the fluctuations and volatility of oil prices changing (lowering/raising) them, in connection with which the prognostic estimates are reliable while maintaining the existing macroeconomic and political conditions [13].

\section{Conclusion}

The processes taking place in the world markets significantly affect the fluctuations and volatility of oil prices changing (lowering/raising) them, in connection with which the prognostic estimates are reliable while maintaining the existing macroeconomic and political conditions. The adequacy of the proposed combined model is confirmed by the conducted retro-forecast (forecast backwards) and allows us to conclude about the further increase in prices for the futures contract for Urals oil in rubles.

\section{References}

[1] Ya.M. Mirkin, Finansovyi konstruktivizm [Financial Constructivism], Lingva-F, Moscow, 2014

[2] Ya.M. Mirkin, Razvivayushchiesya rynki i Rossii v strukture globalnykh finansov: finansovoe budushchee, mnogoletnii trend [Emerging Markets in Russia in the Structure of Global Finance: Financial Future, Multi-Year Trend], Magistr, Moscow, 2015.

[3] I.I. Shuvalov, Globalnye i integratsionnye protsessy v AziatskoTikhookeanskom regione (pravovoe i ekonomicheskoe issledovanie): Mono- grafiya [Global and Integration Processes in the Asia-Pacific Region (a Legal and Economic Study): A Monograph], Infra-M, Moscow, 2016.

[4] Yu.O. Boldareva, Strukturirovannye finansovye instrumenty: opyt, problemy, perspektivy [Structured Financial Instruments: Experience, Problems and Prospects], L.I. Ushvitskii, A.V. Savtsova (eds.), Universitetskaya nauka - regionu: materialy V-i ezhegodnoi nauchno-prakticheskoi konferentsii Severo-Kavkazskogo federalnogo universiteta [University Science - to the Region: Proceedings of the 5th Annual Scientific and Practical Conference of the North-Caucasus Federal University], Izdatelskoinformatsionnyi tsentr "Fabula", Moscow, 2017.

[5] R. Knop, Structured Products, A Complete Toolkit to Face Changing Financial Markets, John Wiley \& Sons Ltd, 2002.

[6] S. Ross, R. Westerfield, B. Jordan, Osnovy korporativnykh finansov. Klyuch $\mathrm{k}$ uspekhu kommercheskoi organizatsii finansovoe planirovanie i upravlenie [Fundamentals of Corporate Finance. The Key to the Success of the Commercial Organization Financial Planning and Management], Moscow, 2001

I. Koch, Sovremennye vozmozhnosti diversifikatsii na rynke aktsii [Modern Possibilities of Diversification in the Stock Market], Rynok tsennykh bumag 7 (2013) 54.

[7] B.B. Rubtsov, Sovremennye fondovye rynki [Modern Stock Markets], Albina Business Books, Moscow, 2008.

[8] M.Yu. Glukhov, Strukturirovannye finansovye produkty: ponyatie i ustroistvo [Structured Financial Products: Notion and Structure], Vestnik Finansovoi Akademii 3(43) (2007) 124-132.

[9] Yu.L. Adno, S.A. Afontsev, O.V. Bogaevskaya, K.R. Voda, F.G Voitolovsky, A.G. Volodin, Rossiya i mir: 2017. Ekonomika vneshnyaya politika. Ezhegodnyi prognoz [Russia and the World: 2017. Economy and Foreign Policy. Annual Forecast], IMEMO RAS; Foundation for Prospective Studies and Initiatives, 2017.

[10] Ya.M. Mirkin, T.V. Zhukova, K.B. Bakhtaraeva, A.V. Komova Kurs dollara i mirovye tseny na syre (neft, gaz, metally): sredne i dolgosrochnyi prognoz [Dollar Rate and World Prices for Raw Materials (Oil, Gas, Metals): Medium and Long-Term Forecast], Bankovskie uslugi 1 (2016) 14-23.

[11] R.R. Duzhinski, E.L. Toroptsev, A.S. Marakhovsky, Ekonomikomatematicheskii analiz staticheskoi ustoichivosti ekonomicheskikh sistem [Economic and Mathematical Analysis of the Static Stability of Economic Systems], Vestnik Severo-kavkazskogo federalnogo universiteta 4(55) (2016) 58-72.

[12] G.K. Rybina, Y.V. Rybina, P.V. Akinin, E.A. Rusetskaya, M.G. Rusetskiy, Instruments Improvement of the Structured Financing within the Supervising Concept of Credit Risk Convertibility, International Journal of Economic Perspectives 11(2) (2017) 1079. 1085 . 